\title{
Article
}

\section{The Effect of Red Mud on Sintering Processes and Minerals of Portland Cement for Roads}

\author{
Xiao Wang ${ }^{1}$, Ke Sun ${ }^{2,3},{\text { Xin } \mathrm{Li}^{3}}^{3}$, Juntao $\mathrm{Ma}^{2,3, *}$ and Zhongtao Luo ${ }^{4}$ \\ 1 School of Materials Science and Engineering, North China University of Water Resources and Electric Power, \\ Zhengzhou 450045, China; wangxiao@ncwu.edu.cn \\ 2 International Joint Research Lab for Eco-Building Materials and Engineering of Henan, North China \\ University of Water Resources and Electric Power, Zhengzhou 450045, China; 18539477859@163.com \\ 3 School of Civil Engineering and Communication, North China University of Water Resources and Electric \\ Power, Zhengzhou 450045, China; LXLXLX0405@163.com \\ 4 School of Materials Science and Engineering, Zhengzhou University, Zhengzhou 450001, China; \\ luozhongtao@zzu.edu.cn \\ * Correspondence: majuntao@ncuw.edu.cn
}

check for updates

Citation: Wang, X.; Sun, K.; Li, X.; Ma, J.; Luo, Z. The Effect of Red Mud on Sintering Processes and Minerals of Portland Cement for Roads. Crystals 2021, 11, 1267. https:// doi.org/10.3390/cryst11101267

Academic Editors: Chongchong Qi and Shujun Zhang

Received: 26 August 2021

Accepted: 14 October 2021

Published: 19 October 202

Publisher's Note: MDPI stays neutral with regard to jurisdictional claims in published maps and institutional affiliations.

Copyright: (c) 2021 by the authors. Licensee MDPI, Basel, Switzerland. This article is an open access article distributed under the terms and conditions of the Creative Commons Attribution (CC BY) license (https:// creativecommons.org/licenses/by/ $4.0 /)$.

\begin{abstract}
As a solid waste generated in the alumina industry, red mud poses a significant environmental hazard and a storage problem. In this study, red mud was added to road cement clinker in order to utilize it. The sintering red mud was first de-alkalized, and then mixed with fly ash, clay, limestone, and sandstone, among other materials, to make Portland cement for road clinker. The effect of the addition of red mud on the thermal decomposition characteristics of Portland cement for roads was studied. The existent states of alkali and radioactive elements in Portland cement for road clinker were investigated by XRD and SEM analysis. The research results showed that the addition of red mud in Portland cement for road raw material significantly promoted the decomposition of carbonates in raw material. The major mineral phases of Portland cement for road clinker were $C_{3} S$ with a polyhedral morphology, quasi-spherical $\mathrm{C}_{2} \mathrm{~S}$, and tubular $\mathrm{C}_{4} \mathrm{AF}$. A small part of the alkali combined with the silicate phase to form a solid solution, and most of the alkali combined with $S$ to form vermiform sulfate in the intermediate phase. The radionuclide ${ }^{226} \mathrm{Ra}$ was mainly distributed in the silicate phase. ${ }^{232} \mathrm{Th}$ was mainly distributed in interstitial phases and then silicate phases, while ${ }^{40} \mathrm{~K}$ was mainly distributed in the interstitial phases.
\end{abstract}

Keywords: red mud; Portland cement for road; thermal decomposition characteristics; alkali; radioactive element; existent states

\section{Introduction}

Red mud is a strong alkaline solid waste that is discharged in the process of alumina production. The average discharge of red mud is $0.7-1.8$ tons per ton of alumina production [1]. Red mud is considered a hazardous industrial waste due to its high alkali content, as well as its small amount of heavy metals and radioactive materials. At present, global red mud reserves are close to 3 billion tons, and the annual growth rate is 120 million tons [2]. As a large alumina production country, China produces more than 30 million tons of red mud annually, and the cumulative stock of red mud is projected to reach 600 million tons by the end of 2021. Due to the lack of economic and feasible technologies for the large-scale utilization of red mud in China, the large number of red mud deposits pose great threats to the environment. For example, on 16 September 2014, due to continuous heavy rains in Zhengzhou, a local collapse occurred in the No. 2 dam of the No. 5 Red Mud Reservoir of the Henan Branch of China Aluminum Corporation [3]. The flood of red mud damaged houses in a nearby village and polluted farmland. Therefore, the utilization of red mud in a comprehensive, efficient, and harmless manner has become urgent and could promote the healthy development of the alumina industry and be crucial for environmental protection. 
Construction material industries, including wall material preparation, cement production, and concrete admixture consume a large amount of industrial waste. According to aluminum smelting methods, red mud can be divided into Bayer process red mud, sintering red mud, and joint process red mud [4]. The basic process to obtain sintering red mud is as follows: first, the bauxite raw material is mixed with a certain amount of sodium carbonate to be calcined in a kiln at high temperature to convert it into sodium aluminate, sodium ferrite, sodium orthosilicate, and calcium titanate. Then, the calcined mixture is dissolved, crystallized, and calcined to obtain alumina. Finally, the separated waste residue after dissolution is sintering red mud. Due to containing more active mineral components (such as $2 \mathrm{CaO} \cdot \mathrm{SiO}_{2}$ ) in red mud, which is produced by the sintering and joint methods, most red mud is usually applied in building materials [4]. Sintering red mud contains large quantities of $\mathrm{SiO}_{2}, \mathrm{Al}_{2} \mathrm{O}_{3}, \mathrm{Fe}_{2} \mathrm{O}_{3}, \mathrm{CaO}$, and silicate minerals. A considerable number of research studies have been carried out on the application of red mud in cement [5-10]. However, because of the high alkali content, composition fluctuation, and high water content of red mud, alkali aggregate reactions are very likely to occur in the application of cement. The alkali in sintering red mud is mainly sodium alkali and potash alkali. K mainly exists as attached alkali, and Na mainly exists as attached alkali and in a chemically bound state. The attached alkali mainly exists as soluble chemical substances, such as $\mathrm{Na}_{2} \mathrm{CO}_{3}$, $\mathrm{NaAlO}_{2}, \mathrm{KOH}, \mathrm{K}_{2} \mathrm{CO}_{3}$, and $\mathrm{NaHCO}_{3}$, which can be removed by washing with water. The chemically bound $\mathrm{Na}$ alkali mainly exists in the states of $\mathrm{NaAlSiO}_{4}, \mathrm{Na}_{2} \mathrm{O} \cdot \mathrm{Al}_{2} \mathrm{O}_{3} \cdot 2 \mathrm{SiO}_{2}$, $\mathrm{Na}_{2} \mathrm{O} \cdot \mathrm{Al}_{2} \mathrm{O}_{3} \cdot 2 \mathrm{SiO}_{2} \cdot x \mathrm{H}_{2} \mathrm{O}$, and $\mathrm{Na}_{2} \mathrm{O} \cdot \mathrm{CaO} \cdot \mathrm{SiO}_{2}$. The alkali aggregate reaction occurring between red mud and cement is the more common and typical alkali-silica reaction. The atmospheric pressure lime method mainly refers to the removal of the bound alkali in the red mud. The typical reaction is the replacement reaction of calcium and sodium. The specific reactions are as follows [11]:

$$
\begin{gathered}
\mathrm{CaO}+\mathrm{H}_{2} \mathrm{O} \rightarrow \mathrm{Ca}(\mathrm{OH})_{2} . \\
\mathrm{Na}_{2} \mathrm{O} \cdot \mathrm{Al}_{2} \mathrm{O}_{3}+\mathrm{Ca}(\mathrm{OH})_{2}(\mathrm{aq}) \rightarrow \mathrm{CaO} \cdot \mathrm{Al}_{2} \mathrm{O}_{3} \cdot 6 \mathrm{H}_{2} \mathrm{O}+\mathrm{NaOH} \\
\mathrm{Na}_{2} \mathrm{CO}_{3}+\mathrm{Ca}(\mathrm{OH})_{2}(\mathrm{aq}) \rightarrow \mathrm{CaCO}_{3}+2 \mathrm{NaOH} \\
\mathrm{Na}_{2} \mathrm{SO}_{4}+\mathrm{Ca}(\mathrm{OH})_{2}(\mathrm{aq}) \rightarrow \mathrm{CaSO}_{4} \cdot 2 \mathrm{H}_{2} \mathrm{O}+2 \mathrm{NaOH} \\
\mathrm{Na}_{2} \mathrm{SiO}_{3}+\mathrm{Ca}(\mathrm{OH})_{2}(\mathrm{aq}) \rightarrow \mathrm{CaO} \cdot \mathrm{SiO}_{2}+\mathrm{H}_{2} \mathrm{O}+2 \mathrm{NaOH} \\
\mathrm{Na}_{2} \mathrm{O} \cdot \mathrm{Al}_{2} \mathrm{O}_{3} \cdot 2 \mathrm{SiO}_{2} \cdot x \mathrm{H}_{2} \mathrm{O}+\mathrm{Ca}(\mathrm{OH})_{2}(\mathrm{aq}) \rightarrow \mathrm{CaO} \cdot \mathrm{Al}_{2} \mathrm{O}_{3} \cdot 2 \mathrm{SiO}_{2} \cdot x \mathrm{H}_{2} \mathrm{O}+2 \mathrm{NaOH} .
\end{gathered}
$$

The radioactivity of red mud also affects its application in cement. If the dosage of red mud exceeds a critical value, the radiation intensity of its manufactured products will not meet the requirements by national standard sand cause damage to the surrounding environment and human health.

In this paper, red mud was dealkalized and used as a raw material for Portland cement. The influence of red mud on the thermal decomposition characteristics of the cement was studied by TG-DTA, SEM-EDS, $\gamma$-ray spectrometry and X-ray diffraction. Furthermore, the alkali and radioactive elements in the road cement clinkers were analyzed. This research lays a theoretical foundation for the large-scale application of red mud in cement production.

\section{Materials and Experimental Methods}

\subsection{Materials}

Red mud was taken from the red mud sintering process of the Zhengzhou Branch of China Great Wall Aluminum Industry. The XRD patterns of red mud from the sintering process are shown in Figure 1. The alkali content of the red mud was high, which limited the dosage that could be used in cement. Therefore, the sintering red mud needed to be dealkalized first. The red mud was dealkalizedusing the atmospheric pressure lime method. The dealkalizer was industrial lime. The dosage of industrial lime was $10 \mathrm{wt} . \%$, 
and the liquid-to-solid ratio was 3:1. The dealkalizing process was performed as follows: first, the red mud, industrial lime, and water were mixed; then, the mixture was heated to $90{ }^{\circ} \mathrm{C}$ and allowed to react for $7 \mathrm{~h}$; finally, the dealkalized red mud was obtained after filtration and drying.

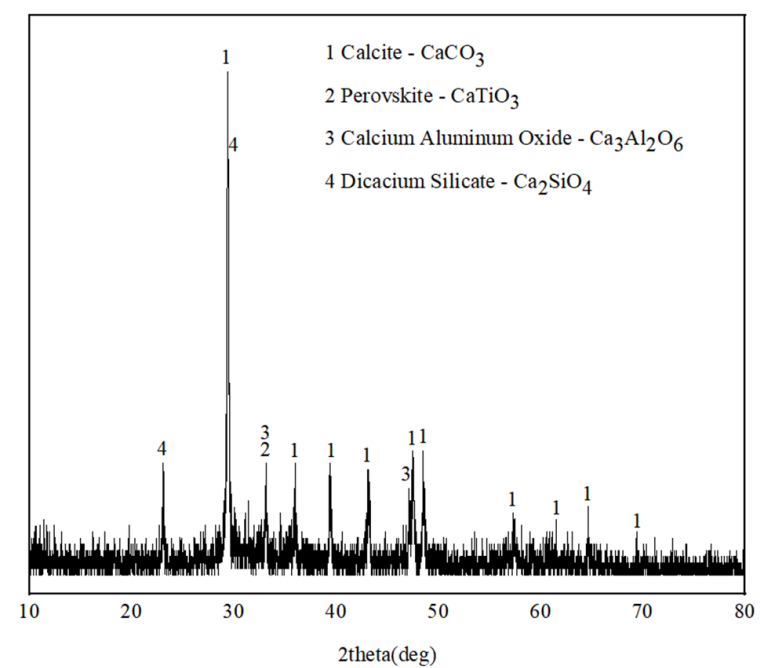

Figure 1. The $\mathrm{XRD}$ patterns of red mud from the sintering process.

The chemical composition of dealkalized red mud is shown in Table 1. Limestone, sandstone, and fly ash were obtained from Tianrui Group Zhengzhou Cement Co., Ltd. Their chemical compositions are also shown in Table 1. Other materials, including iron oxide and $\mathrm{KOH}$, were pure reagents for chemical analysis.

Table 1. Chemical composition of raw materials (wt.\%).

\begin{tabular}{|c|c|c|c|c|c|c|c|c|c|c|}
\hline Oxide & $\mathrm{SiO}_{2}$ & $\mathrm{Al}_{2} \mathrm{O}_{3}$ & $\mathrm{Fe}_{2} \mathrm{O}_{3}$ & $\mathrm{CaO}$ & $\mathrm{MgO}$ & $\mathrm{K}_{2} \mathrm{O}$ & $\mathrm{Na}_{2} \mathrm{O}$ & $\mathrm{SO}_{3}$ & $\begin{array}{l}\text { Loss on } \\
\text { Ignition }\end{array}$ & Others \\
\hline Sintering red mud & 17.33 & 6.91 & 13.23 & 30.33 & 1.47 & 1.21 & 2.33 & 0.92 & 18.70 & 7.57 \\
\hline Dealkalized sintering red mud & 15.95 & 6.34 & 12.50 & 34.35 & 1.76 & 0.50 & 0.30 & 0.86 & 24.50 & 2.94 \\
\hline Limestone & 4.47 & 1.71 & 0.73 & 55.35 & 1.37 & 0.64 & 0.07 & 0.18 & 35.18 & 0.30 \\
\hline Sandstone & 89.37 & 2.55 & 2.27 & 0.59 & 0.23 & 0.77 & 0.03 & 0.02 & 3.79 & 0.38 \\
\hline Fly ash & 52.37 & 28.80 & 5.56 & 2.89 & 2.02 & 0.54 & 1.45 & - & 3.69 & 2.68 \\
\hline Clay & 67.31 & 14.50 & 5.55 & 1.95 & 1.77 & 1.23 & 1.11 & - & 4.87 & 1.71 \\
\hline
\end{tabular}

\subsection{Preparation of Portland Cement for Road}

The actual batching scheme used for Portland road cement is shown in Table 2. KBS is a kind of Portland road cement according to Chinese National Standard GB 13693-2005 (Portland Cement for Road), which was used as a blank control group without red mud. In order to study the physical and mechanical properties of Portland road cement, according to Chinese National Standard GB/T17671-1999 (Testing Method of Cement Mortar Strength), a TYE-200B cement mortar flexural and compressive machine was employed to test the 3 day and 28 day compressive and flexural strength of the test block. According to Chinese National Standard GB/T1346-2001 (Standard Test Method for Water Consumption, Setting Time, and Stability of Cement) and Chinese National Standard JC/T603-2004 (Dry Shrinkage Test Method of Cement Mortar), the water consumption at standard consistency, setting time, and dry shrinkage performance of each group of cement were tested. 
Table 2. Composition of the designed clinker of Portland cement for roads.

\begin{tabular}{cccccccccc}
\hline \multirow{2}{*}{ Samples } & \multicolumn{4}{c}{ Raw Material Content } & \multicolumn{3}{c}{ Clinker Rate Values } \\
\cline { 2 - 9 } & $\begin{array}{c}\text { Limestone } \\
\text { (wt.\%) }\end{array}$ & $\begin{array}{c}\text { Dealkalied Red Mud } \\
\text { (wt.\%) }\end{array}$ & $\begin{array}{c}\text { Sandstone } \\
\text { (wt.\%) }\end{array}$ & $\begin{array}{c}\text { Clay } \\
\text { (wt. \%) }\end{array}$ & $\begin{array}{c}\text { Fly Ash } \\
\text { (wt. } \%)\end{array}$ & $\begin{array}{c}\text { Iron Oxide } \\
\text { (wt.\%) }\end{array}$ & KH & SM & IM \\
\hline S1 & 68.31 & 23.00 & 6.90 & 0.00 & 1.79 & 0.00 & 0.90 & 1.97 & 0.96 \\
S2 & 66.00 & 26.00 & 6.21 & 0.00 & 1.79 & 0.00 & 0.90 & 1.82 & 0.90 \\
S3 & 64.41 & 28.00 & 5.80 & 0.00 & 1.79 & 0.00 & 0.90 & 1.73 & 0.87 \\
KBS & 83.41 & 0.00 & 2.90 & 9.50 & 1.79 & 2.40 & 0.90 & 1.95 & 0.96 \\
\hline
\end{tabular}

The physical and mechanical properties of Portland cement are shown in Table 3, and the stability of each group of cement is qualified. All kinds of raw materials passed an 80 micron square-hole sieve. According to Chinese National Standard GB 13693-2005 (Portland Cement for Road), the compressive and flexural strengths of 42.5 Portland road cement aged for 3 days were $21 \mathrm{MPa}$ and $4.0 \mathrm{MPa}$, respectively. Additionally, the compressive and flexural strengths of 42.5 Portland road cement aged for 28 days were 42.5 $\mathrm{MPa}$ and $7.0 \mathrm{MPa}$, respectively. As it can be seen from Table 3, the shrinkage decreased with the increase in red mud fraction from S1 to S3, the reason being that the $\mathrm{C}_{4} \mathrm{AF}$ in Portland road cement increased with the increase in red mud fraction. The S3 cement had a long initial setting time and a poor compressive strength, the reason for this phenomenon being that excessive red mud content led to excessive liquid phase in the S3 clinker sintering system, which affected the formation of $C_{3} S$. The content of $C_{3} S$ in $S 3$ clinker was very small, and the content of $\mathrm{C}_{2} \mathrm{~S}$ was great. This resulted in $\mathrm{S} 3$ cement having a longer setting time and poor compressive strength.

Table 3. Physical and mechanical performance of Portland cement for roads.

\begin{tabular}{|c|c|c|c|c|c|c|c|c|c|c|}
\hline \multirow{2}{*}{ Samples } & \multicolumn{3}{|c|}{$\begin{array}{c}\text { Compressive Strength } \\
(\mathrm{MPa})\end{array}$} & \multicolumn{3}{|c|}{$\begin{array}{l}\text { Flexural Strength } \\
(\mathrm{MPa})\end{array}$} & \multirow{2}{*}{$\begin{array}{c}\text { Standard } \\
\text { Consistency } \\
\text { Water } \\
\text { Consumption } \\
(\%)\end{array}$} & \multicolumn{2}{|c|}{$\begin{array}{l}\text { Setting Time } \\
\text { (h:min) }\end{array}$} & \multirow{2}{*}{$\begin{array}{c}28 \text { day Dry } \\
\text { Shrinkage } \\
(\%)\end{array}$} \\
\hline & 3 days & 7 days & 28 days & 3 days & 7 days & 28 days & & $\begin{array}{c}\text { Initial } \\
\text { Setting } \\
\text { Time }\end{array}$ & $\begin{array}{l}\text { Final } \\
\text { Setting } \\
\text { Time }\end{array}$ & \\
\hline KBS & 34.20 & 43.17 & 53.15 & 6.02 & 7.72 & 8.17 & 28.4 & $1: 22$ & $3: 37$ & 0.048 \\
\hline $\mathrm{S} 1$ & 26.80 & 38.30 & 57.50 & 6.17 & 7.95 & 8.78 & 27.4 & $1: 32$ & $3: 20$ & 0.043 \\
\hline $\mathrm{S} 2$ & 27.40 & 39.20 & 55.30 & 6.27 & 7.90 & 8.45 & 27.4 & $1: 36$ & $3: 17$ & 0.037 \\
\hline S3 & 18.00 & 29.20 & 39.95 & 4.67 & 6.67 & 7.33 & 27.2 & $2: 15$ & $3: 49$ & 0.033 \\
\hline
\end{tabular}

\subsection{X-ray Diffraction of Sintering Red Mud and Portland Cement for Roads}

XRD analysis was conducted to analyze the phase of sintering red mud and Portland road cement clinker using an Uitima IV X-ray diffractometer with a $\mathrm{Cu}-\mathrm{K} \alpha$ radiation source. The measurements range of $2 \theta$ values was $10-80^{\circ}$.

\subsection{TG-DSC Analysis of Portland Cement for Roads}

TG-DSC was performed using a PYRIS series comprehensive thermal analyzer. The heating rate was $25^{\circ} \mathrm{C} / \mathrm{min}$. The max temperature was $1000^{\circ} \mathrm{C}$. The atmosphere was air, and the sample mass was $5 \mathrm{mg}$.

\subsection{Experiments on Microstructure of Cement Clinker and Occurrence State of Alkali and Radioactive Elements Therein}

In order to study the influence of radioactive elements $\left({ }^{226} \mathrm{Ra},{ }^{232} \mathrm{Th}\right.$, and $\left.{ }^{40} \mathrm{~K}\right)$ in red mud on the radioactivity of Portland road cement, according to the method specified in Chinese National Standard GB6566-2001 (Radionuclide Limit of Building Materials), the specific activities of ${ }^{226} \mathrm{Ra},{ }^{232} \mathrm{Th}$, and ${ }^{40} \mathrm{~K}$ in red mud road Portland cement were measured using an FP90041B low-background multichannel gamma spectrometer. The resolution of the gamma spectrometer was $2.1 \mathrm{keV}$, and the integrated background count 
rate was $120 \mathrm{~min}^{-1}$. The safety performance of red mud road silicate cement was evaluated. Calculations referenced formulas of internal and external illumination index (Equations (1) and (2), respectively).

$$
\begin{gathered}
I_{r}=\frac{C_{R a}}{370 \mathrm{Bqkg}^{-1}}+\frac{C_{T h}}{260 \mathrm{Bqkg}^{-1}}+\frac{C_{K}}{4200 \mathrm{Bqkg}^{-1}}, . \\
I_{R a}=\frac{C_{R a}}{200},
\end{gathered}
$$

where $I_{R a}$ is the internal radiation index, $I_{r}$ is the external radiation index, and $C_{R a}, C_{T h}$, and $C_{K}$ are the specific radioactivity of radioactive elements ${ }^{226} \mathrm{Ra},{ }^{232} \mathrm{Th}$, and ${ }^{40} \mathrm{~K}$ in the sample, respectively.

In order to study the occurrence state of radioactive elements in red mud of Portland cement for road clinker, S2 clinker with a high red mud content and good physical and mechanical properties was selected. According to the principle of selective dissolution and the method proposed in [12,13], $5.0 \mathrm{~g}$ of S2 clinker with fineness less than $8 \mu \mathrm{m}$ was ground to extract the silicate phase using sucrose- $\mathrm{KOH}$ solution. A volume of $300 \mathrm{~mL}$ of distilled water was added to a $500 \mathrm{~mL}$ beaker, heated to $95^{\circ} \mathrm{C}$, and continuously stirred. Then, $30 \mathrm{~g}$ of sucrose, $30 \mathrm{~g}$ of $\mathrm{KOH}$, and $5 \mathrm{~g}$ of fine cement clinker were added successively. After continuous stirring at $95^{\circ} \mathrm{C}$ for $30 \mathrm{~min}$, the silicate mineral phase $(\mathrm{CxS})$ was obtained by vacuum filtration using slow filter paper and a Brinell funnel, after which the residue was repeatedly washed with anhydrous ethanol and transferred to the surface dish. After drying to constant weight at $80{ }^{\circ} \mathrm{C}$, the silicate mineral phase $(\mathrm{CxS})$ was obtained and sealed. These operations were repeated to obtain a silicate phase weighing $200 \mathrm{~g}$. The clinker and the extracted silicate phase were analyzed by XRD using an Ultima IV X-ray diffractometer. The radioactivity of the clinker and extracted silicate mineral phase were measured using anFP90041B low-background multichannel gamma spectrometer. Lastly, a JSM-7800F thermal field-emission scanning electron microscope was used for surface scanning of clinker to find the distribution of radioactive elements ${ }^{226} \mathrm{Ra},{ }^{232} \mathrm{Th}$, and ${ }^{40} \mathrm{~K}$.

\section{Results and Discussion}

3.1. Effect of Red Mud on Thermal Decomposition Characteristics of Portland Cement for Use as a Raw Material in Roads

In order to study the effects of red mud on the thermal decomposition characteristics of Portland road cement raw material and the sintering process of Portland road cement clinker, the formula and blank samples of three groups of red mud were subjected to TG-DSC analysis. The decomposition temperatures of these samples were determined; the results of TG-DSC are shown in Table 4 and Figure 2.

Table 4. Thermal analysis results of Portland road cement clinker.

\begin{tabular}{ccccc}
\hline & & Decomposition Temperature $\left({ }^{\circ} \mathrm{C}\right)$ & & \\
Sample & $\begin{array}{c}\text { Initial Decomposition } \\
\text { Temperature }\end{array}$ & $\begin{array}{c}\text { Fastest Decomposition } \\
\text { Temperature }\end{array}$ & $\begin{array}{c}\text { End Decomposition } \\
\text { Temperature }\end{array}$ & $\begin{array}{c}\text { Weight Loss } \\
\text { Rate }(\%)\end{array}$ \\
\hline S1 & 659.2 & 815.9 & 837.9 & 35.25 \\
S2 & 653.4 & 804.0 & 827.3 & 35.15 \\
S3 & 649.2 & 800.7 & 825.8 & 35.26 \\
KBS & 671.8 & 814.4 & 841.3 & 35.90 \\
\hline
\end{tabular}

The results show that the initial decomposition temperature of the S1 raw material sample with $23 \mathrm{wt} \%$ red mud content was $659.2^{\circ} \mathrm{C}$. The temperature at which its decomposition occurred most rapidly (referred here as the fasted decomposition temperature) was $815.9{ }^{\circ} \mathrm{C}$, and the decomposition end temperature was $837.9^{\circ} \mathrm{C}$. Compared with the blank sample of KBS, the initial decomposition temperature and the decomposition end temperature of the S1 raw material samples were lower, and the fastest decomposition 
temperature was similar. The decomposition temperatures of S2 raw material samples with a red mud content of $26 \mathrm{wt} \%$ were lower than those of S1. The decomposition temperature of the S3 raw material sample with a red mud content of $28 \mathrm{wt} \%$ was the lowest. In general, the addition of red mud significantly promoted the carbonate decomposition of Portland road cement raw materials. For S1, S2, and S3, with the increase in red mud content, the decomposition temperatures of raw material were significantly reduced. On the one hand, some trace components $(\mathrm{Na}, \mathrm{K}, \mathrm{S}$, etc.) in red mud could play a role in mineralization in the sintering process of Portland road cement and promote the decomposition of carbonate in raw materials. On the other hand, the increase in red mud content could reduce the SM and IM values of the raw material. In the cement production process, it is beneficial to reduce the energy consumption of the raw material preheating process if the thermal decomposition temperature of the raw material can be reduced. Red mud is used as a raw material to prepare Portland road cement, which can reduce energy consumption during cement production and save energy.

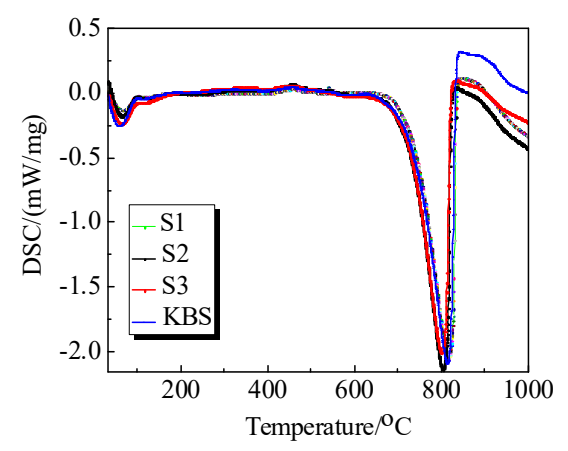

(a)

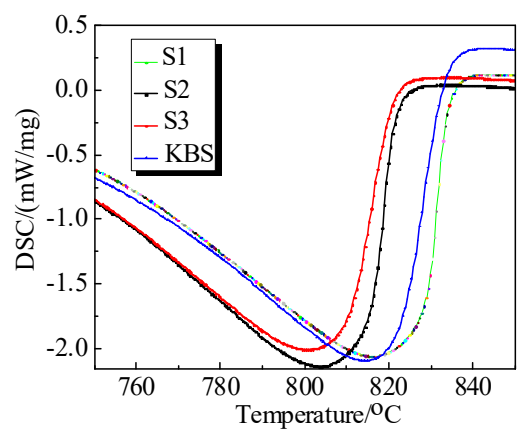

(b)

Figure 2. TG-DSC analysis curve of Portland road cement clinker: (a) graph over the temperature range measured; (b) enlarged graph over a limited temperature range.

\subsection{Occurrence of Alkali in Portland Road Cement Clinker}

As can be seen from Table 3, the compressive and flexural strength levels of S3 after 3, 7 , and 28 days were all far lower than that of KBS. For good cement, its 28 day compressive strength should exceed $42.5 \mathrm{MPa}$; the 28 day compressive strength of S3 was $39.3 \mathrm{MPa}$. More importantly, as shown in Table 5, the external radiation index (Ir) of S3 was 1.02, which exceeded standards. Therefore, the most suitable dosage of red mud in Portland cement for roads was $26 \mathrm{wt} . \%$ (S2). For this reason, in order to industrialize red mud cement, the S2 sample was chosen as the object of further research.

Table 5. Results of specific radioactivity for $\mathrm{C}_{X} \mathrm{~S}$ and clinker of Portland road cement.

\begin{tabular}{ccccccc}
\hline Sample & $\left.{ }^{\mathbf{2 2 6}} \mathbf{R a} \mathbf{( B q} / \mathbf{k g}\right)$ & $\left.{ }^{\mathbf{2 3 2}} \mathbf{T h} \mathbf{( B q} / \mathbf{k g}\right)$ & $\left.{ }^{\mathbf{4 0}} \mathbf{K} \mathbf{( B q} / \mathbf{k g}\right)$ & $\mathbf{I}_{\mathbf{R a}}$ & $\mathbf{I}_{\mathbf{r}}$ & Total Specific Activity (Bq/kg) \\
\hline KBS & 38.3 & 31.3 & 308.5 & 0.19 & 0.30 & 378.1 \\
S1 & 108.6 & 94 & 304.8 & 0.54 & 0.73 & 507.4 \\
S2 & 136.3 & 126.2 & 309.1 & 0.68 & 0.93 & 601.9 \\
S3 & 151.3 & 138.9 & 311.7 & 0.76 & 1.02 & 460.2 \\
C3S, C2S & 311.1 & 91 & 58.1 & 1.6 & 1.2 & \\
\hline
\end{tabular}

Figure 3 shows the SEM-EDS analysis results of Portland road cement clinker in group S2. According to Chinese National Standard GB 13693-2005 (Portland Cement for Road), the content of $\mathrm{C}_{4} \mathrm{AF}$ was more than $16 \mathrm{wt} . \%$ and that of $\mathrm{C}_{3} \mathrm{~A}$ was less than $5 \mathrm{wt} . \%$. From the SEM photos of the clinker, it can be seen that the main mineral composition of Portland road cement clinker was $\mathrm{C}_{3} \mathrm{~S}, \mathrm{C}_{2} \mathrm{~S}$, and $\mathrm{C}_{4} \mathrm{AF}$. 

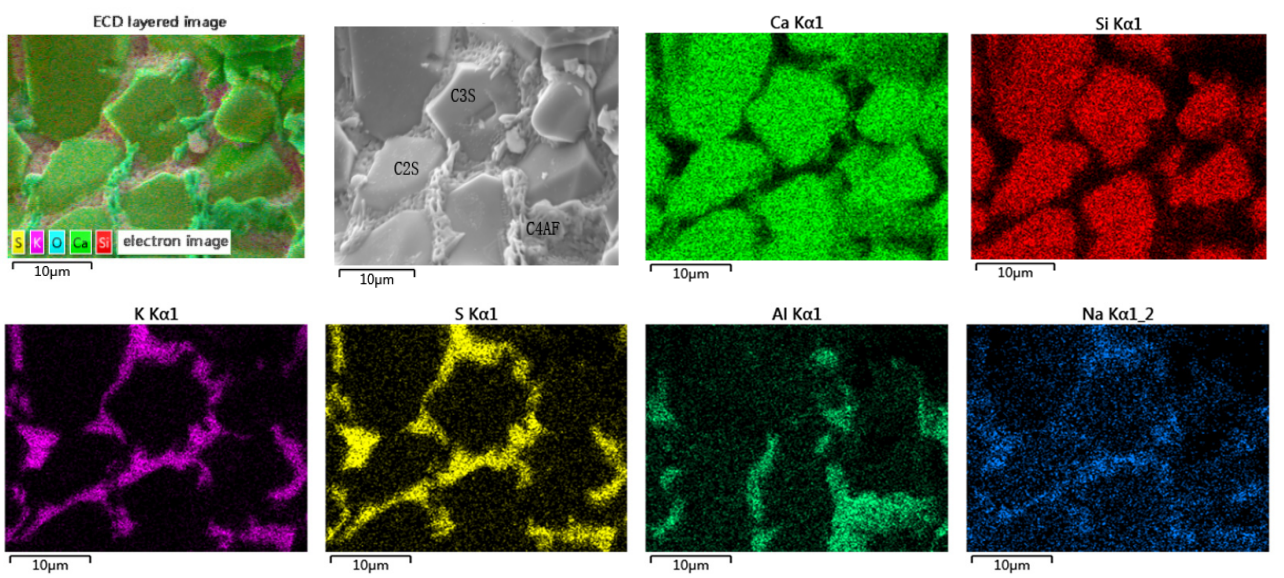

Figure 3. The SEM map scanning images of Portland road cement $(\times 1000)$.

From the SEM-EDS map scanning results of Portland road cement clinker shown in Figure 3, it can be seen that the distribution shapes of the K element and S element were consistent, and that the distribution of $\mathrm{K}$ in other locations was very small. This indicated that $\mathrm{K}$ was mainly distributed in the intermediate phase in the form of sulfate formed by binding with $\mathrm{S}$. The distribution of $\mathrm{Na}$ in the intermediate phase was greater, and it was also uniformly distributed in the silicate phase. The surface distribution image was basically consistent with that of $S$, indicating that more $\mathrm{Na}$ combined with sulfur to form sulfate, and the remaining $\mathrm{Na}$ existed in the silicate phase in a solid solution. In summary, potassium in red mud Portland road cement clinker mainly existed in the intermediate phase in the form of sulfate. The distribution of $\mathrm{Na}$ was relatively uniform. More $\mathrm{Na}$ existed in the intermediate phase in the form of sulfate, and the remaining $\mathrm{Na}$ existed in the silicate phase as a solid solution. Additionally, as can be seen in Figure 3, Al was mainly distributed in the intermediate phase in the form of $\mathrm{C}_{4} \mathrm{AF}$.

\subsection{Occurrence of Radioactive Elementsin Portland Road Cement Clinker}

Figure 4 [14] illustrates the results of the XRD analysis of Portland road cement clinker before and after extraction. The clinker in the XRD pattern was S2. The $\mathrm{C}_{4} \mathrm{AF}$ diffraction peaks of Portland road cement clinker mineral disappeared after extraction and were only present in the silicate phase. This indicates that the main mineral composition of the extracted clinker was the silicate phase. Table 5 shows the specific activity of Portland road cement clinker and the extracted silicate phase. The extracted silicate phase was compared with S2 clinker; ${ }^{226} \mathrm{Ra}$ specific activity increased by $174.8 \mathrm{~Bq} / \mathrm{kg}$ and specific activity of ${ }^{232} \mathrm{Th}$ decreased by $35.2 \mathrm{~Bq} / \mathrm{kg}$. This shows that, in Portland road cement linker, ${ }^{226} \mathrm{Ra}$ was mainly distributed in the silicate mineral phase, and ${ }^{232} \mathrm{Th}$ was present in the greatest quantity in the intermediate phase. However, ${ }^{40} \mathrm{~K}$ was mainly distributed in the intermediate phase. The external radiation index $(\mathrm{Ir})$ and internal radiation index $\left(\mathrm{I}_{\mathrm{Ra}}\right)$ of KBS group were 0.30 and 0.19 , respectively. Compared with the KBS group without red mud, the radioactivity of the clinker with red mud was much higher. From S1 to S3, the radioactivity of cement clinker increased with increasing red mud content. According to the method specified in Chinese National Standard GB6566-2001 (Radionuclide Limit of Building Materials), the radioactivities of natural radionuclides should be satisfied simultaneously, i.e., $\mathrm{I}_{\mathrm{Ra}} \leq 1$ and $\mathrm{I}_{\mathrm{r}} \leq 1$, in building materials. The external radiation index $\left(\mathrm{I}_{\mathrm{r}}\right)$ of $\mathrm{S} 3$ was 1.02 , which exceeded standards. 


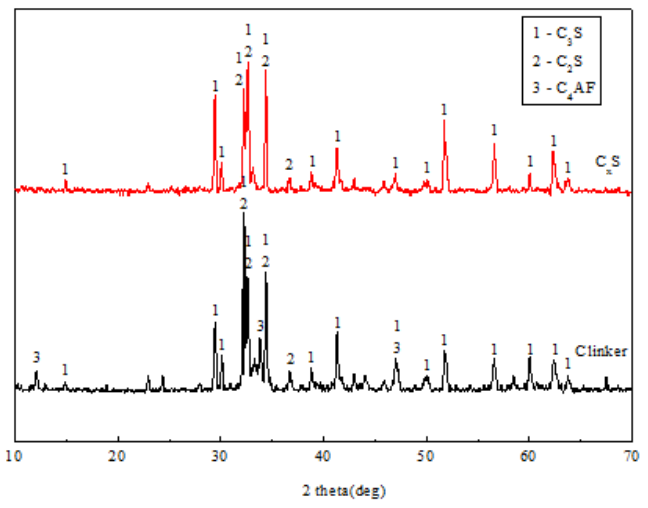

Figure 4. X-ray diffraction of Portland road cement clinker and CxS.

$\mathrm{Ra}$ is a typical alkaline-earth metal element, belonging to the same main group as $\mathrm{Ca}$ and $\mathrm{Ba}$; therefore, their chemical properties are very similar. The effect of Ba ion doping on the mineral phase of cement clinker was studied in the literature [15-18], and the results showed that Ba was mainly dissolved in Belite by replacing Ca in an isomorphic manner; $\mathrm{Ra}$ can also be dissolved in Belite by replacing $\mathrm{Ca}$ as Ba did. However, Th only has a valence state of +4 , which is stable even in an oxidation environment. It is difficult to incorporate in nature, but it can be incorporated via adsorption on iron oxide. The distribution of Th in the cement's mineral phase was similar to that of Fe, which was mainly distributed in the $\mathrm{C}_{4} \mathrm{AF}$ phase, indicating that some Th will be incorporated via adsorption on iron oxide during the calcination process of the clinker and form an iron solid/melt. K mainly existed in a sulfate mineral phase, and a small amount of $\mathrm{K}$ may have been dissolved in silicate minerals. It can also be seen from Figure 3 that $\mathrm{K}$ was distributed in both a silicate mineral phase and an intermediate phase in Portland road cement clinker. $\mathrm{K}$ was also distributed in the intermediate phase. The distribution shapes of $\mathrm{K}$ and $\mathrm{S}$ were very similar. The results also show that most of the $\mathrm{K}$ and $\mathrm{S}$ combined to form sulfates in the intermediate phase during the calcination process of the Portland road cement, and a small amount of $\mathrm{K}$ was dissolved in silicate minerals. Therefore, the SEM analysis results further indicated that K was mainly distributed in the intermediate phase of Portland road cement.

\section{Conclusions}

The thermal decomposition characteristics and mineral constituents of Portland road cement for road presented the following characteristics:

1. The thermal decomposition temperature of each group of raw materials with red mud was lower than that of raw materials without red mud. With the increase in the red mud content, the thermal decomposition temperature of Portland road cement raw materials gradually decreased. The addition of red mud significantly promoted the carbonate decomposition process of Portland road cement raw materials.

2. Alkali in Portland road cement clinker mainly existed in the intermediate phase. The distribution of $\mathrm{Na}$ was relatively uniform. More $\mathrm{Na}$ existed in the intermediate phase in the form of sulfate, and the remaining $\mathrm{Na}$ existed in the silicate phase in the form of a solid solution. $\mathrm{K}$ was mainly distributed in the intermediate phase in the form of sulfate combined with $\mathrm{S}$.

3. Under the principle of maximum red mud content, the $\mathrm{S} 2$ group with $26 \mathrm{wt} \%$ red mud content had excellent physical and mechanical properties. Therefore, the optimal red mud content in Portland road cement was determined to be $26 \mathrm{wt} \%$.

4. In Portland road cement clinker, Ra was mainly distributed in the silicate mineral phase in an isomorphic manner, replacing Ca solid solution in Belite. Th and K were mainly distributed in the intermediate phase. 
Author Contributions: Conceptualization, X.W. and J.M.; methodology, X.W.; software, K.S.; vali dation, X.W. and K.S.; formal analysis, X.W., K.S., X.L. and J.M.; investigation, X.W., K.S., X.L. and J.M.; resources, X.W., J.M. and Z.L.; data curation, X.W., S.K. and X.L.; writing-original draft preparation, X.W. and K.S.; writing-review and editing, X.W. and J.M.; visualization, X.W.; supervision, X.W., J.M. and Z.L.; project administration, X.W., Z.L.; funding acquisition, J.M. All authors have read and agreed to the published version of the manuscript.

Funding: This research was funded by [Engineering Research Center of Embankment Safety and Disease Prevention and Control of Ministry of Water Resources] grant number [DFZX202009].

Conflicts of Interest: The authors declare no conflict of interest.

\section{References}

1. Liu, J.; Li, X.; Zhou, C. Mechanical and thermal properties of modified red mud-reinforced phenolic foams. Polym. Int. 2018, 67, 528-534. [CrossRef]

2. Power, G.; Gräfe, M.; Klauber, C. Bauxite residue issues: II. Options for residue utilization. Hydrometallargy 2011, 108, 11-32.

3. The Piping Hazard of Chinalco Henan Red Mud Reservoir Has Been Controlled. Available online: https://www.163.com/news/ article/A6D0JP6O00014Q4P.html (accessed on 18 September 2014).

4. Zhao, Y.; Liang, N.; Chen, H.; Li, Y. Preparation and properties of sintering red mud unburned road brick using orthogonal experiments. Constr. Build. Mater. 2019, 238, 117739. [CrossRef]

5. Pontikes, Y.; Nikolopoulos, P.; Angelopoulos, G.N. Thermal behaviour of clay mixtures with bauxite residue for the production of heavy-clay ceramics. J. Eur. Ceram. Soc. 2007, 27, 1645-1649. [CrossRef]

6. Singh, M.; Upadhayay, S.; Prasad, P. Preparation of special cements from red mud. Waste Manag. 1996, 45, 665-670. [CrossRef]

7. Vangelatos, I.; Angelopoulos, G.N.; Boufounos, D. Utilization of ferroalumina as raw material in the production of Ordinary Portland Cement. J. Hazard. Mater. 2009, 168, 473-478. [CrossRef] [PubMed]

8. Duvallet, T.; Rathbone, R.F.; Henke, K.R.; Jewell, R.B. Low-energy Low $\mathrm{CO}_{2}$-emitting cements produced from coal combustion by-products and red mud. In Proceedings of the World of Coal Ash Conference, Lexington, KY, USA, 7 May 2009; Volume 44, pp. 1-13.

9. Wang, W.; Wang, X.; Zhang, J.; Ma, C. Experimental investigation and modeling of sulfoaluminate cement preparation using desulfurization gypsum and red mud. Ind. Eng. Chem. Res. 2013, 52, 1261-1266. [CrossRef]

10. Wu, F.; Li, L.; Zhou, D.J. Influence of Bayer Redmud on the Alkalinity of Cement based Material Pore Solution and the Strength Development. Fly Ash Compr. Util. 2011, 2, 7-10.

11. Li, J.W. Study on the Dealkalization Process and Alkali Recovery of Sintering Red Mud. Master's Thesis, Zhengzhou University, Zhengzhou, China, 2012.

12. Tian Bu, T.M.; Li, W.H.; Yang, J.N. Cement Production Study by Utilizing Sintering Red Mud. Cem. Technol. 2005, 2, 67-68.

13. Feng, M.F.; Wen, X.P.; Yu, W.G. Study on the chemical phase separation method sulfur and fluorine containing clinker. Bull. Chin. Ceram. Soc. 1986, 5, 45-52.

14. Wang, X.; Ma, J.T.; Zhang, L.; Yang, J.J. Radioactive Element Distribution Characteristics of Red Mud based Field Road Cement before and after Hydration. J. Wuhan Univ. Technol. Mater. 2018, 33, 452-458. [CrossRef]

15. Gutteridge, W.A. On the dissolution of the interstitial phases in Portland cement. Cem. Concr. Res. 1979, 9, 319-324. [CrossRef]

16. Chen, Y.K.; Wang, S.B. Study for the effects and Mechanisms of Barium Sulphate on the Formation of Alkali-Containing Clinker. J. Wuhan Univ. Technol. 1994, 16, 16-22.

17. Lv, H.; Zhong, J.Y.; Fan, Y.M. The Effect of Inner-Added Bao on the Mineral Composition and Properties of $\mathrm{C}_{2} \mathrm{~S}-\mathrm{C}_{4} \mathrm{~A}_{3} \overline{\mathrm{S}}-$ $\mathrm{C}_{4} \mathrm{AF}-\mathrm{C} \overline{\mathrm{S}}$ System. J. South China Univ. Technol. 1990, 18, 32-40.

18. Guo, X.Y.; Lu, L.C.; Wang, S.D. Influence of Barium Adding on Composition and Performance of Alite-Rich Portland Cement Clinker. J. Chin. Ceram. Soc. 2009, 37, 2083-2090. 